\title{
Identification of phosphorylation proteins in response to water deficit during wheat flag leaf and grain development
}

Fei Luo ${ }^{1+}$, Xiong Deng ${ }^{1 \dagger}$, Yue Liu ${ }^{1}$ and Yueming Yan ${ }^{1,2^{*}}$

\begin{abstract}
Background: Wheat (Triticum aestivum L.) serves as important grain crop widely cultivated in the world, which is often suffered by drought stress in natural conditions. As one of the most important post translation modifications, protein phosphorylation widely participates in plant abiotic stress regulation. In this study, we performed the first comparative analysis of phosphorylated protein characterization in flag leaves and developing grains of elite Chinese bread wheat cultivar Zhongmai 175 under water deficit by combining with proteomic approach and Pro-Q Diamond gel staining.

Results: Field experiment showed that water deficit caused significant reduction of plant height, tiller number, ear length and grain yield. 2-DE and Pro-Q Diamond gel staining analysis showed that 58 proteins were phosphorylated among 112 differentially accumulated proteins in response to water deficit, including 20 in the flag leaves and 38 in the developing grains. The phosphorylated proteins from flag leaves mainly involved in photosynthesis, carbohydrate and energy metabolism, while those from developing grains were closely related with detoxification and defense, protein, carbohydrate and energy metabolism. Particularly, water deficit resulted in significant downregulation of phosphorylated modification level in the flag leaves, which could affect photosynthesis and grain yield. However, some important phosphorylated proteins involved in stress defense, energy metabolism and starch biosynthesis were upregulated under water deficit, which could benefit drought tolerance, accelerate grain filling and shorten grain developing time.

Conclusions: The modification level of those identified proteins from flag leaves and grains had great changes when wheat was suffered from water deficit, indicating that phosphoproteins played a key role in response to drought stress. Our results provide new insights into the molecular mechanisms how phosphoproteins respond to drought stress and thus reduce production.
\end{abstract}

Keywords: Bread wheat, Phosphorylated proteins, Water deficit, Flag leaves, Developing grains

\section{Background}

As one of the most important grain crops, wheat (Triticum aestivum $\mathrm{L}$.) is widely cultivated in the world due to its value as a stable source of saccharides and proteins, and its ability to adapt to different surviving environment. However, most agricultural areas where wheat mainly spread over strongly depend on natural rainfall,

\footnotetext{
*Correspondence: yanym@cnu.edu.cn

${ }^{\dagger}$ Fei Luo and Xiong Deng contributed equally to this work

${ }^{1}$ College of Life Science, Capital Normal University, Beijing 100048, China

Full list of author information is available at the end of the article
}

including almost all arid and semiarid areas (Cai et al. 2012). In recent years, climate changing, especially global warming, has exacerbated the effects of drought stress on crop production. In general, temperature rising $1{ }^{\circ} \mathrm{C}$ can produce a decrease in yield of up to $10 \%$ (Lobell et al. 2011).

Drought is one of the most common abiotic stresses, which significantly affects crop production (Fedoroff et al. 2010). Drought stress induces a series of physiological and biochemical changes in plants, strongly interferes cellular homeostasis and causes morphological changes, 
e.g. repression of cell growth and photosynthesis, and activation of respiration. Moreover, when two experimental groups are respectively exposed to water sufficiency and water deficiency conditions during grain filling, the results of stored carbon remobilization in wheat are apparently different: one group is senescence and the other accelerates grain filling (Yang et al. 2000, 2001). However, telluric plants have developed specific mechanisms to response and tolerance to short- and long-term adverse environments, particularly to drought (Harb et al. 2010). For example, plants can accumulate reactive oxygen species (ROS) and proteins to enhance drought tolerance (Zhu 2002). In addition, when encountered drought stress, plant root caps synthesize abscisic acid (ABA) to trigger a signaling cascade in guard cells, and then leads to stomatal closure and reduction of water loss (MacRobbie 1998).

Plant leaves are the largest organ of photosynthesis with highest photosynthetic efficiency, providing an important source of carbohydrate for developing grains. Therefore they serve as the ultimate yield-limiting factor (Slafer et al. 1990). As reported, the contribution of wheat flag leaves to grain yield is up to $41-43 \%$ (Araus and Tapia 1987). However, photosynthesis is particularly sensitive to water deficit and the photosynthetic rate is negatively related to water content (Lawlor and Cornic 2002). Meanwhile, drought causes foliar stoma limitation and reduces air exchanges (Cornic 2000). In addition, metabolic repair can be suppressed by drought, causing the limitation of photosynthesis and significant reduction of carbon assimilation and utilization capacity (Reddy et al. 2004). Grain endosperm in wheat consists of about $70 \%$ starch and $14 \%$ proteins, which are the major determinant of yield and quality (Johansson et al. 2001; Donner and Mesdag 2000). These reserve substances are rapidly synthesized and accumulated after flowering, and this process involves lots of genes and enzymes (Cao et al. 2015; Yu et al. 2016). At least four types of enzymes, phosphorylated by other kinases in the amyloplast of higher plant endosperm, are involved in starch biosynthesis such as branching enzymes, ADP glucose pyrophosphorylase (AGPase), starch synthases (SS) and debranching enzymes (DBE).

Protein phosphorylation, as one of the most important protein posttranslational modifications (PTMs), is often reversible and transient (Hunter and Karin 1992). Serine, threonine, and tyrosine (Ser/Thr/Tyr) are the key phosphorylated modification sites in proteins (Stock et al. 1989; Cohen 2002; Aivaliotis et al. 2009), Plenty of enzymes perform their functions in signaling pathways, protein abundance or activity regulation via protein phosphorylation (Engelsberger and Schulze 2012). The phosphorylation of some key proteins involved in
ABA signal transduction pathway contributes to cellular growth and abiotic stress response (Thingholm et al. 2009; Zhang et al. 2014a). Protein phosphorylation also regulates many essential biochemical processes such as DNA transcription, protein translation, and energy metabolism (Kersten et al. 2009).

In recent years, extensive phosphoproteomic analyses in different plant species were performed to explore the molecular basis of plant growth and abiotic stress responses such as Arobidopsis thaliana (Umezawa et al. 2013), Brachypodium distachyon (Lv et al. 2014a, b; Yuan et al. 2016), rice (Chang et al. 2012), wheat (Zhang et al. 2014a, b; Dong et al. 2015; Lv et al. 2016), maize ( $\mathrm{Hu}$ et al. 2015a, b) and barley (Horie et al. 2011). Particularly, Pro-Q Diamond phosphoprotein staining can specially bind to the part of phosphate of phosphoproteins as well as phosphoamino acids. Therefore it serves as an efficient mean to rapidly detect phosphorylated proteins (SilvaSanchez et al. 2015). Through Pro-Q Diamond staining, protein phosphorylated modification was widely present in germinating seeds (Dong et al. 2015), developing grains (Guo et al. 2012; Zhang et al. 2014b), starch granules (Chen et al. 2014, 2017; Cao et al. 2015) and seedling leaves response to salt stress ( $\mathrm{Lv}$ et al. 2016). Various abiotic stresses such as drought and salt can induce significant changes in protein phosphorylated levels (Zhang et al. 2014a; Bian et al. 2017). Thus, protein phosphorylation plays key roles in wheat growth and development, and starch biosynthesis as well as in response to various adverse environments. However, to our knowledge, the phosphorylated protein characterization in wheat developing flag leaves and grains and their potential roles in regulating grain development and yield formation are still not clear.

In this study, we aim to characterize the phosphorylated proteins in wheat developing flag leaves and grains at 20 days postanthesis (DPA) under field water-deficit treatment and to reveal the potential roles of phosphorylated proteins involved in drought stress response and grain development. Our results provide new evidence for further understanding the molecular mechanisms of flag leaves and grains synergistically respond to drought stress.

\section{Materials and methods}

\section{Wheat materials, field drought treatments and sampling}

Chinese elite bread wheat cultivar Zhongmai 175 (Triticum aestivum L.) was used as material and planted in the experimental station of China Agricultural University (CAU), Wuqiao, Hebei Province $\left(116^{\circ} 37^{\prime} 23^{\prime \prime} \mathrm{E}\right.$ and $37^{\circ} 16^{\prime} 02^{\prime \prime} \mathrm{N}$ ) during 2016-2017 wheat growing season. Basic fertility of the experiment plot was measured before sowing. The organic matter, total nitrogen, hydrolysable 
nitrogen, available phosphorus and available potassium in the topsoil $(0-20 \mathrm{~cm})$ of the experimental plots were $12.1 \mathrm{~g} \mathrm{~kg}^{-1}, 1.0 \mathrm{~g} \mathrm{~kg}^{-1}, 106.7 \mathrm{mg} \mathrm{kg}{ }^{-1}, 33.8 \mathrm{mg} \mathrm{kg}$ and $183.4 \mathrm{mg} \mathrm{kg}^{-1}$, respectively. Total precipitation was $128 \mathrm{~mm}$ at 2016-2017 wheat growing season, lower than the annual mean amount (130-180 mm).

Field experiments contained two irrigation treatment groups in three biological replicates: drought treatment group without irrigation after sowing and control group with two times of irrigation after sowing watered $75 \mathrm{~mm}$ at the jointing and anthesis stage, respectively. Each experimental plot was $8 \times 4 \mathrm{~m}$ with rows spaced at $0.16 \mathrm{~m}$ and $1 \mathrm{~m}$ interval between control and treatment groups was maintained to minimize the effects of adjacent plots. The watering amount was measured by a flow meter. Soil samples at 20 DPA were collected from $0 \mathrm{~m}$ increments to a depth of $2 \mathrm{~m}$ with a soil corer and soil water content was determined by using the oven-drying method (Gardner 1986).

Before sowing, relative water content of target field was irrigated to $80.5 \%$ of the field water capacity at 0-200 cm soil layer, and then seeds were sowed when soil water content got to $80 \%$ (Chu et al. 2016). The Zadoks scale was used to categorize crop developmental stages (Zadoks et al. 1974). The plants were marked after flowering, and then flag leaves and developing grains at 20 DPA in three biological replicates were harvested, and immediately immerged into liquid nitrogen prior to use. After maturity, main agronomic traits and grain yield were tested.

\section{Protein extraction}

Proteins from flag leaves and grains were extracted according to the previous report (Zhang et al. 2014b) with minor modifications. Leaves and grain samples (each $0.5 \mathrm{~g}$ ) from three biological replicates were ground into fine powder by liquid nitrogen, then mixed with $1 \mathrm{~mL}$ of extraction buffer consisting of $50 \mathrm{mM}$ Tris- $\mathrm{HCl}(\mathrm{pH} 8.0)$, $0.1 \mathrm{M} \mathrm{KCl}, 5 \mathrm{mM}$ EDTA and 30\% sucrose. PhosSTOP phosphatase inhibitor cocktail (1 tablet/10 mL, Roche, Basel, Switzerland) was added. After placing for $15 \mathrm{~min}$, the samples were shaken vigorously for $30 \mathrm{~min}$ at room temperature, and then centrifuged to divide mixture. Protein supernatants were precipitated with a one-quarter volume of cold $10 \%$ trichloroacetic acid at $-20^{\circ} \mathrm{C}$ for $4 \mathrm{~h}$. The precipitated proteins were rinsed with cold acetone $\left(-80^{\circ} \mathrm{C}\right)$ and then centrifuged three times at $13,000 \mathrm{~g}$ for $10 \mathrm{~min}$. After frozen dryly, $300 \mu \mathrm{L}$ solubilization buffer was added and placed at room-temperature for $4 \mathrm{~h}$. The protein concentrations were quantitated by 2-D Quant Kit (Amersham Bioscience, USA) and the protein solution was stored at $-80^{\circ} \mathrm{C}$ for later use.

\section{2-DE}

The differentially accumulated proteins (DAPs) from three biological replicates were separated by two-dimensional electrophoresis (2-DE) based on Lv et al. (2014b). The isoelectric focusing (IEF) was performed using $18 \mathrm{~cm}$ linear gradient IPG strip (GE Healthcare, Little Chalfont, UK). After IEF, the equilibration solution (1\% DTT) was applied to equilibrate the strips for $15 \mathrm{~min}$ and then the second equilibration was performed with $2.5 \%$ $\mathrm{w} / \mathrm{v}$ iodoacetamide. Subsequently, the strips were loaded on the top of $12 \%$ SDS-polyacrylamide gels for SDSPAGE, and 2-DE gels were stained by Coomassie blue. The ImageMaster 2D Platinum 7.0 (GE Healthcare, USA) was used to analyze the images and only those with significant and biological reproducible changes (abundance variation at least twofold, Student's $t$ Test, $p<0.05$ ) were used as DAP spots.

\section{Detection of phosphorylated proteins by Pro-Q Diamond gel staining}

2-DE gels were stained with Pro-Q Diamond (Invitrogen, USA) to detect the different level of phosphoproteins by the previous method (Zhang et al. 2014a). The gels were fixed twice for $30 \mathrm{~min} /$ each time and washed three times with $\mathrm{ddH}_{2} \mathrm{O}$ for $10 \mathrm{~min} /$ each time. Subsequently, the gels were incubated in Pro-Q Diamond staining in darkness for $2 \mathrm{~h}$ and destained with $20 \%$ acetonitrile in $50 \mathrm{mM}$ sodium acetate ( $\mathrm{pH} 4.0)$ four times (30 min each). The gels were scanned on a TyphoonTM 9400 scanner (GE Healthcare, USA) with a $532 \mathrm{~nm}$ excitation laser and a $610 \mathrm{~nm}$ long pass filter. The gels were stained with CBB to visualize total phosphoproteins after fluorescent image acquisition. The phosphorylated proteins were identified through comparison between 2-DE gels and Pro-Q Diamond gel staining results.

\section{MALDI-TOF/TOF-MS}

The DAP and phosphorylated protein spots identified were manually excised from the 2-DE gels and digested with trypsin as the reported method (Lv et al. 2016). Matrix-assisted laser desorption/ionization time-offlight/time-of-flight mass spectrometer (MALDI-TOF/ TOF-MS) was used to identify the DAPs by ABI 4800 Proteomics Analyzer. The MS/MS spectra were searched in Viridiplantae (green plant) sequences in the nonredundant National Center for Biotechnology Information (NCBI) database and Triticum NCBI database. MASCOT software (ver. 2.1; Matrix Science, London, UK) was used and all searches were evaluated based on the significant scores obtained from MASCOT. A significance threshold of $p<0.05$ was used, and the protein score CI\% and total ion score $\mathrm{CI} \%$ were both set to $>95 \%$. 
Validation of phosphorylated proteins by Western blotting Western blotting was performed to further verify the phosphorylated proteins identified by Pro-Q Diamond staining by using Anti-Phosphoserine/threonine/tyrosine monoclonal antibody from Abcam (Cat. No. SPM101, MA, USA) according to the previous report (Chen et al. 2014).

\section{Bioinformatics analysis}

Protein function was classified based on the annotation from UniProt (Wang et al. 2015). The subcellular localization was predicted according to FUEL-mLoc Server (http://bioinfo.eie.polyu.edu.hk/FUEL-mLoc/), WoLF PSORT (http://www.genscript.com/wolf-psort.html), CELLO version 2.5 (http://cello.life.nctu.edu.tw/), PlantmPLoc (http://www.csbio.sjtu.edu.cn/bioinf/plant-multi /) and UniProtKB. Biological statistic analyses were performed by SPSS statistics software (ver. 19.0; SPSS Inc., Chicago, IL, USA) to intuitively view the results. The relative expression quantity of proteins between wellwatered and water-deficit group was represented as the average of three replicates and compared by one-way ANOVA. Cluster 3.0 and visualized with Java TreeView were used for protein clustering analysis. Hierarchical clustering of the expression profiles was carried out based on the log transformed fold change values of protein spots and average linkage clustering method with Euclidean distance similarity metric was used (Wang et al. 2017). Meanwhile, NetPhos 3.1 Server (Blom et al. 1999) (http://www.cbs.dtu.dk/services/NetPhos/) was used to predict phosphorylation sites among the identified phosphorylated proteins.

\section{Results}

\section{Soil water content, agronomic trait and yield changes} under water deficit

The changes of relative soil water content between 0 and $2 \mathrm{~m}$ depths in the control group and drought treatment groups at 20 DPA were shown in Fig. 1. The results showed that the relative soil water content of 0 to $1.4 \mathrm{~m}$ depth had obvious discrepancy between the control and drought treatment. Thus, severe drought in the treatment group occurred in the $0-60 \mathrm{~cm}$ soil layer, and mild drought in the $60-140 \mathrm{~cm}$ soil layer based on the grade of agricultural drought in GB/T 32136-2015 (Lv et al. 2015).

Water deficit resulted in significant changes of main agronomic traits and grain yield. In the field, plant leaves became yellower and plant height was more lethargic (Fig. 2a, b) and wheat ears and grains were smaller and yellower in the treatment group than the control group (Fig. 2c, d). Thus, plant height, ear length, tiller numbers, grain number per spike and 1000-grain weight were

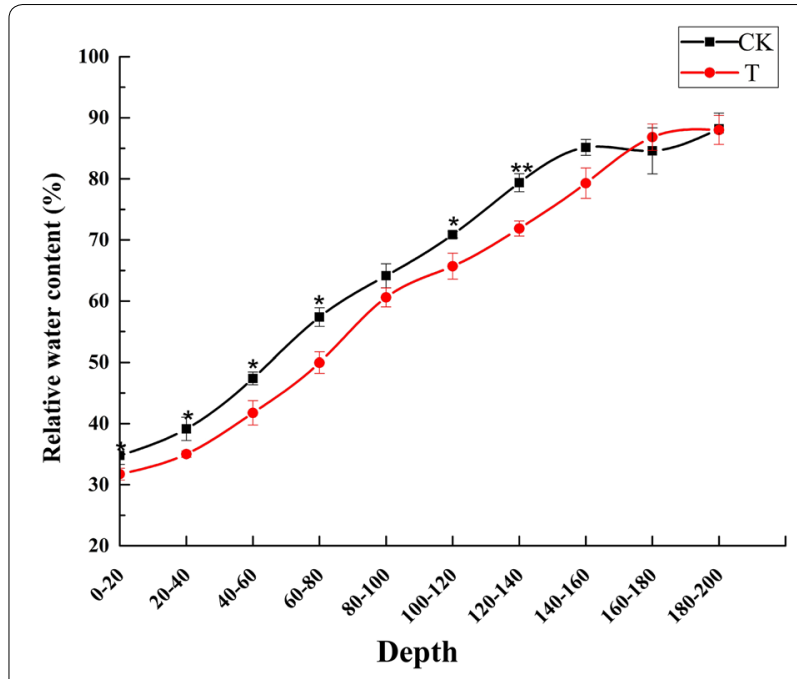

Fig. 1 Soil relative water content at 20 DPA. Soil relative water content was measured at $2 \mathrm{~m}$ depth of soil in the control (CK) and drought treatment ( $\mathrm{T}$ ) groups. Statistically significant differences compared to the control were calculated based on an independent Student's t-tests. Asterisks indicate significant different $\left({ }^{*} p<0.05\right.$; $\left.{ }^{* *} p<0.01\right)$. Error bars indicate standard errors of three biological replicates

significantly decreased. Ultimately, drought treatment caused significant reduction of grain yield, up to $19.23 \%$ (Additional file 1: Table S1).

Identification of differentially accumulated proteins (DAPs) responsive to water deficit in flag leaves and developing grains

2-DE and tandem mass spectrometry identified 41 and 71 DAP spots in response to water deficit, which respectively contained 36 and 64 unique proteins at 20 DPA in flag leaves and grains (Fig. 3). The detailed information and peptide sequences of the identified proteins are listed in Additional file 1: Tables S2A, B and S3A, B. The function annotation from UniProt showed that 100 unique proteins were classified into 7 functional categories: carbon metabolism, stress defense, energy metabolism, photosynthesis, protein metabolism, storage substance biosynthesis. In the flag leaves, the DAPs were mainly involved in energy metabolism (34.17\%), photosynthesis $(31.70 \%)$ and protein metabolism $(14.63 \%)$ while those in the developing grains were mainly related to stress defense (23.94\%), protein metabolism $(16.90 \%)$ and storage substance biosynthesis (16.90\%) (Fig. 4a). Subcellular localization showed that most of the DAPs in flag leaves and grains were located in chloroplast $(73.17 \%)$ and cytoplasm (45.07\%), respectively (Fig. 4b, c). These results indicate that the foremost function of 
$\mathbf{a}$

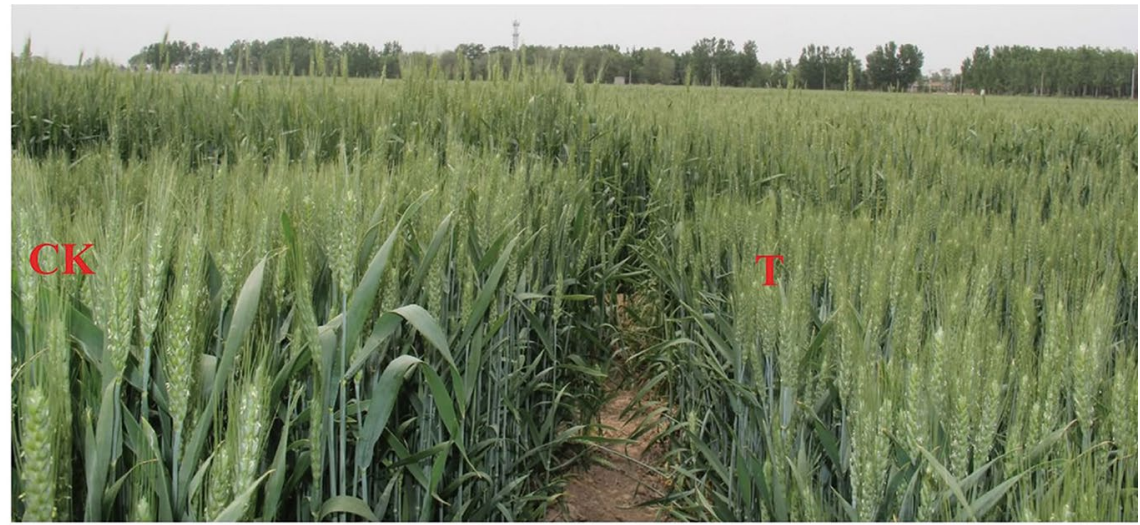

b
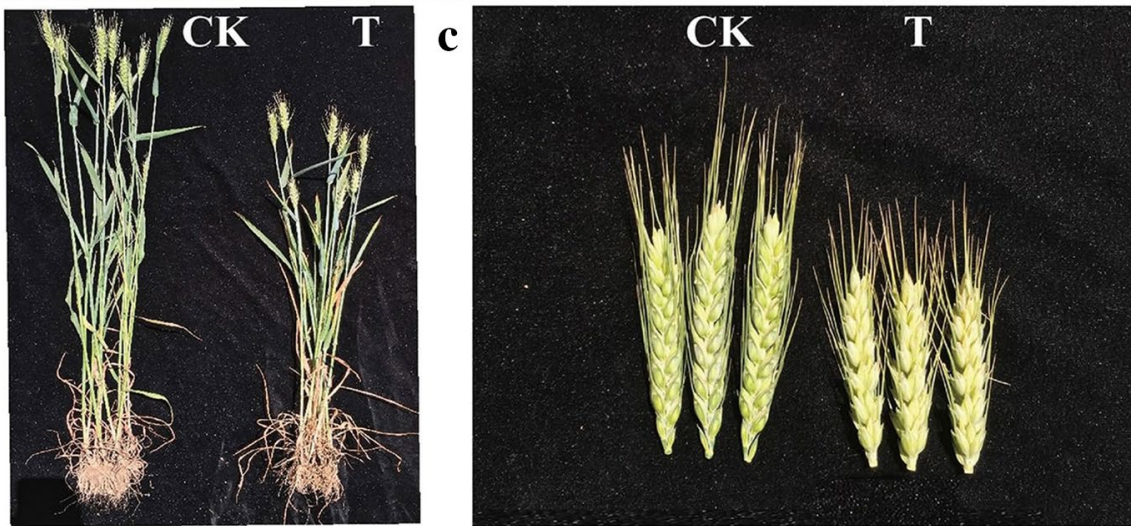

d

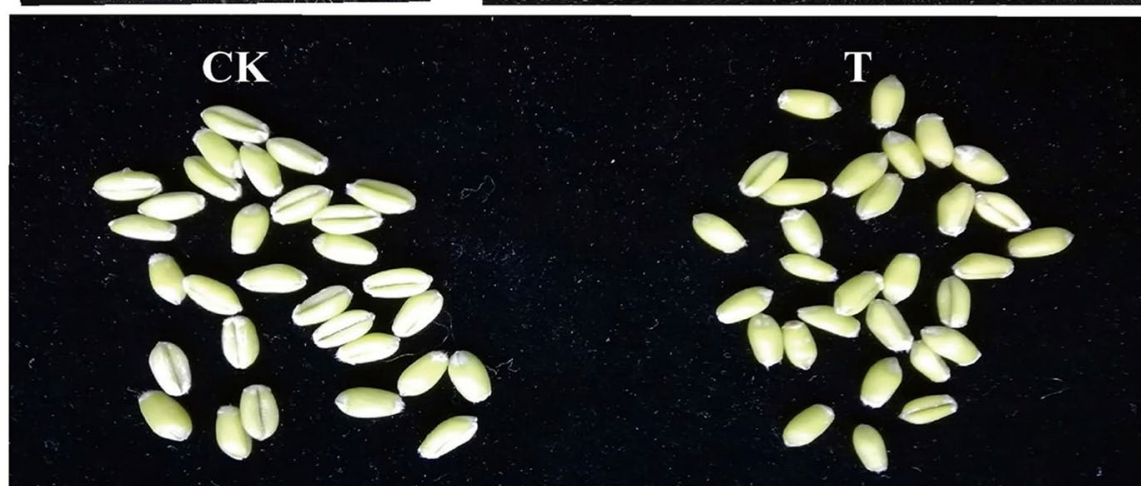

Fig. 2 Plant phenotypes under stress treatment and CK. a, b Plant height compared at 20 DPA between CK and drought treatment groups. c Ear length at 20 DPA under drought treatment. d Grain appearance at 20 DPA under drought treatment

flag leaves is photosynthesis while grain proteins play important roles in abiotic stress defense and reserve substance synthesis.

\section{Characterization of phosphorylated proteins in the developing flag leaves and grains under water deficit}

Through comparison of 2-DE (Fig. 3), Pro-Q Diamond staining (Fig. 5), and tandem mass spectrometry results, 20 and 38 phosphorylated DAP spots in response to water deficit were respectively identified in flag leaves and developing grains, which were individually represented
18 and 38 unique phosphoproteins in flag leaves and developing grains (Table 1). According to the functional categories (Fig. 4a), the phosphorylated proteins in flag leaves were mainly involved in energy metabolism (35\%) and photosynthesis (35\%), while those in the developing grains mainly participated in stress defense (26.31\%), protein metabolism (23.68\%), and energy metabolism $(18.42 \%)$. Most of the phosphorylated proteins in flag leaves were present in chloroplast (80\%) (Fig. 4b), and $52.63 \%$ grain phosphorylated proteins were located in cytoplasm (Fig. 4c). Thus, drought stress mainly affected photosynthesis and energy metabolism in the flag leaves, 


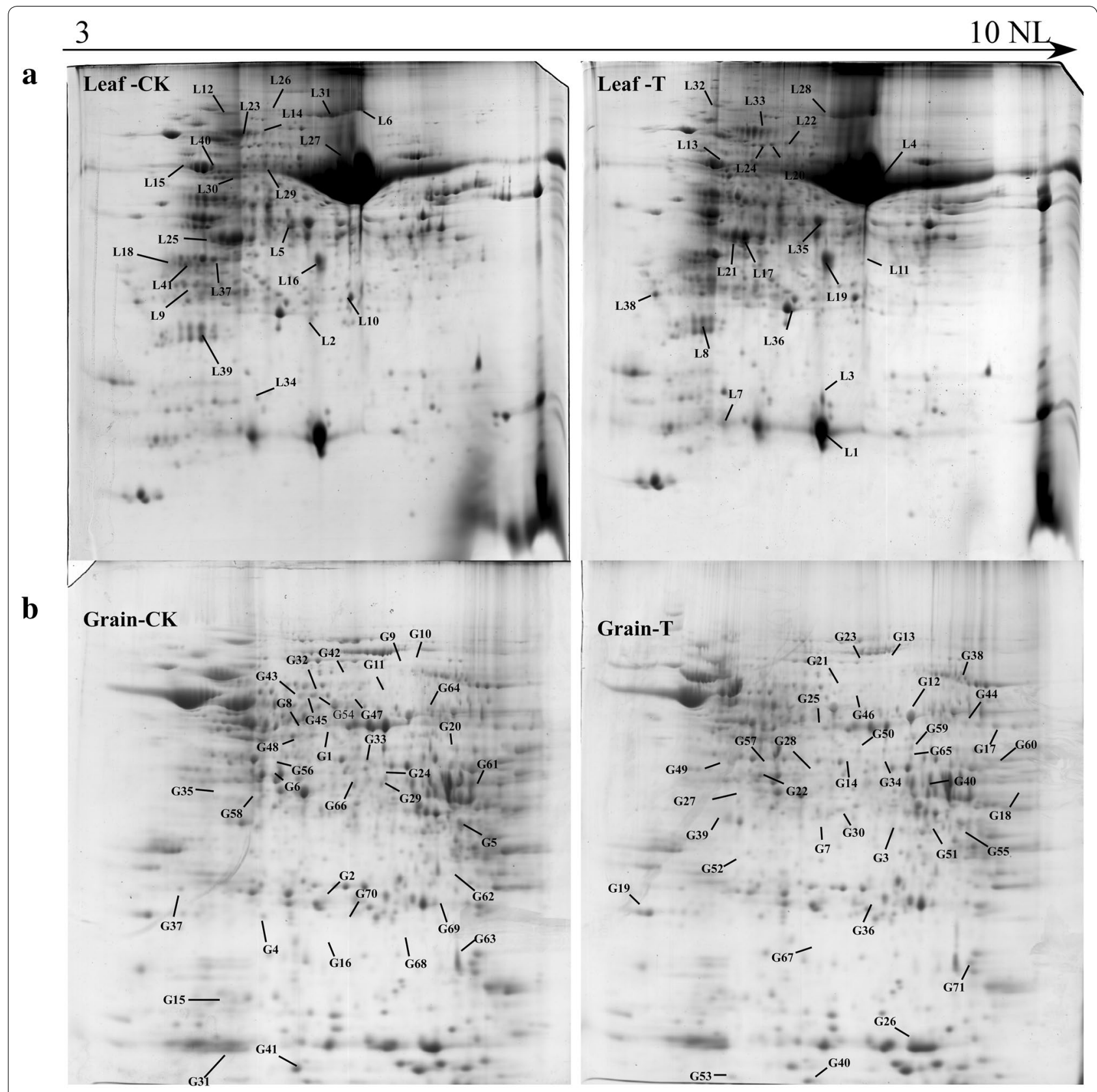

Fig. 3 2-DE gel images of flag leaves and developing grains at 20 DPA in Zhongmai 175 under drought stress. a Flag leaf 2-DE gels of CK and drought treatment. $\mathbf{b}$ Grain 2-DE gels of CK and drought treatment

and stress/defense, energy metabolism, protein trafficking and degradation in the developing grains.

Associated with 2-DE gels and Pro-Q Diamond gel staining, some isoforms of DAPs resulted from phosphoprotein were found. In the flag leaves, ribulose1,5-bisphosphate carboxylase/oxygenase large subunit had three different isoforms (L4, L5 and L6). Meanwhile, the phosphorylation of both L4 and L5 was detected by Pro-Q Diamond. In the developing grains, ribulose1,5-bisphosphate carboxylase/oxygenase large subunit (G1 and G59) and fructose-bisphosphate aldolase cytoplasmic isozyme (G2 and G3) also had different isoforms, of which G2 and G3 was individually phosphorylated (Table 1). 


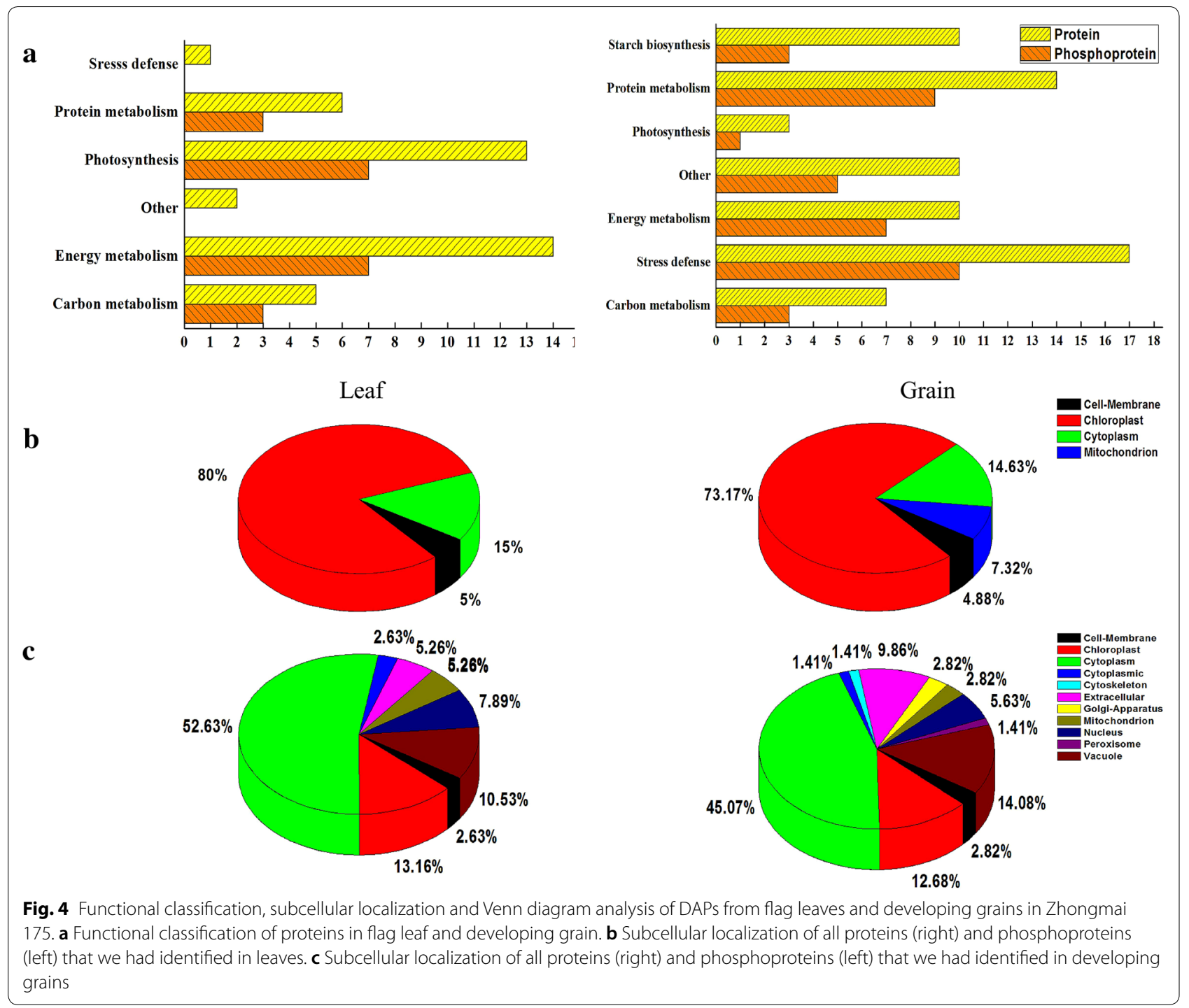

\section{Hierarchical clustering analysis of DAPs}

and phosphorylated proteins in response to water deficit Hierarchical clustering analysis was conducted to reveal the accumulation patterns of DAPs and phosphorylated proteins under water deficit (Fig. 6). The results showed that $24(58.54 \%)$ and 45 (63.38\%) DAPs from flag leaves and developing grains were significantly upregulated, respectively (Fig. 6a). In the flag leaves, the upregulated DAPs were mainly related to energy metabolism while the downregulated DAPs were majorly involved in photosynthesis. In the developing grains, stress defense and energy metabolism related DAPs were drastically increased whereas those related to protein metabolism were downregulated.
The accumulation patterns of the phosphorylated proteins under water deficit showed that $13(65 \%)$ and 25 $(65.78 \%)$ phosphoproteins were upregulated in the flag leaves and grains, respectively (Fig. 6b). We found that most phosphoproteins involved in carbon metabolism and energy metabolism were upregulated in flag leaves, but some important phosphoproteins participating in photosynthesis were downregulated. In the developing grains, the modification levels of those related to energy metabolism, stress defense and storage substance biosynthesis increased. Thus, most phosphoproteins involved in photosynthesis were both downregulated whereas those related to energy metabolism, drought stress response and storage substance biosynthesis were generally 


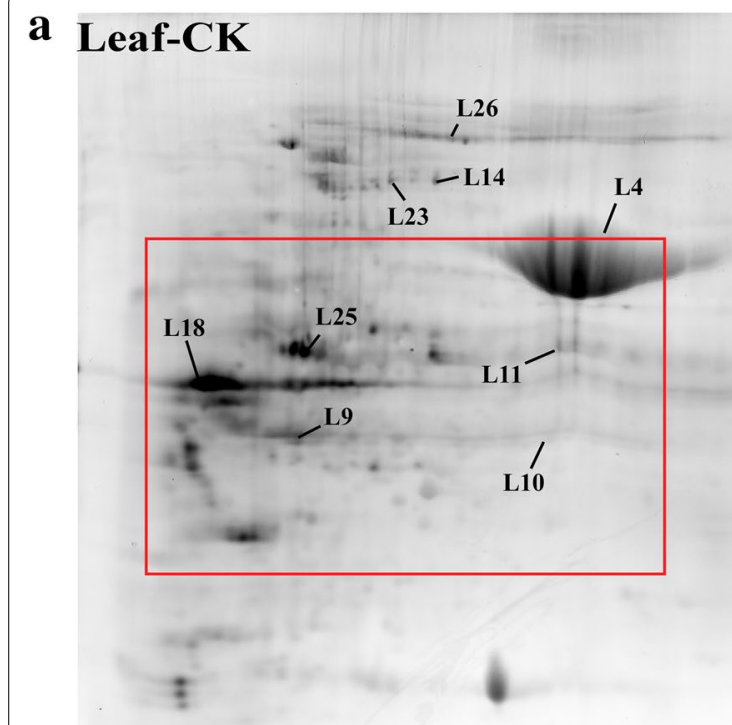

\section{Leaf-T}

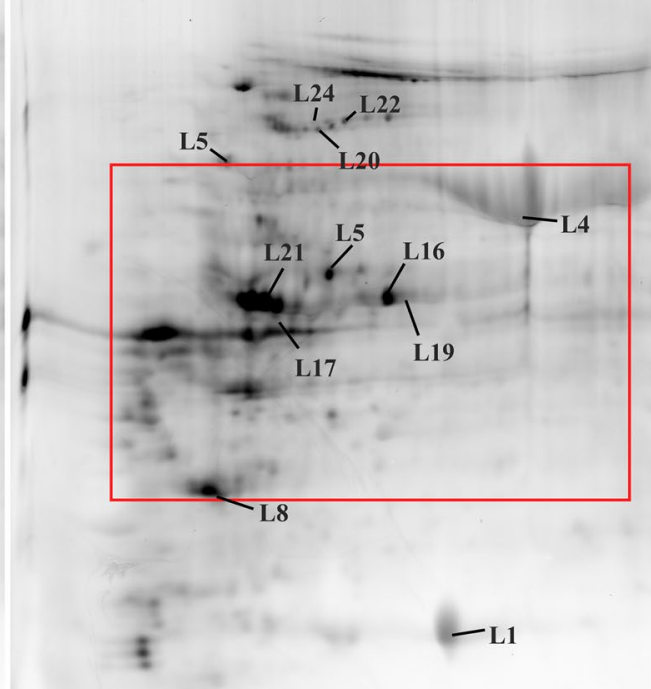

\section{b Grain-CK}

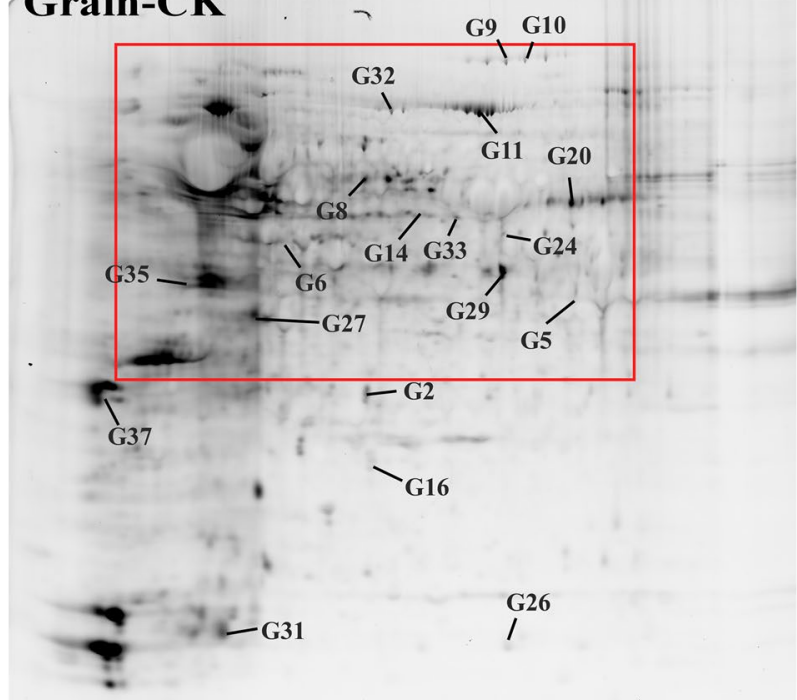

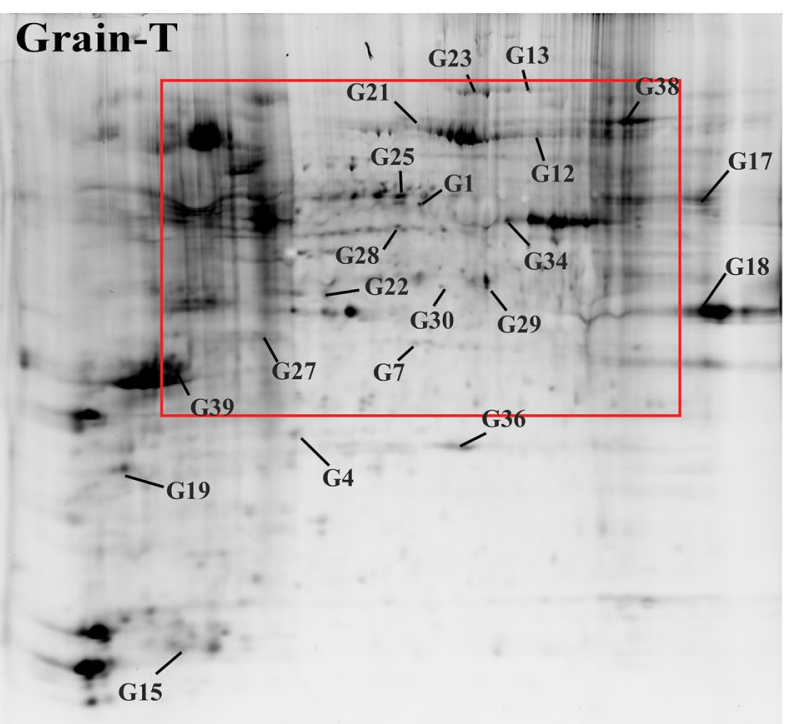

Fig. 5 Detection of phosphorylated proteins in 2-DE gels by Pro-Q diamond staining. a The image of Pro-Q diamond staining in flag leaves. b The image of Pro-Q diamond staining in grains

upregulated in both phosphorylated modification level and protein level. Particularly, ribulose bisphosphate carboxylase/oxygenase activase A (L10 and L11) was only identified in flag leaves under well-watered group and translationally-controlled tumor protein (G19) was only identified in the developing grains under drought treatment group. This suggests that water deficit caused the dephosphorylation of ribulose bisphosphate carboxylase/ oxygenase activase A and specific phosphorylation of translationally-controlled tumor protein.

\section{Verification of phosphorylated proteins by phosphorylated site prediction and Western blotting}

To provide further supporting for the presence of the phosphorylated proteins identified by Pro-Q Diamond staining, the phosphorylated sites of all 58 
Table 1 Representative phosphorylated proteins identified by MALDI-TOF/TOF-MS and Pro-Q staining

\begin{tabular}{|c|c|c|c|c|c|c|c|}
\hline Spot no. & Protein name & Protein score & Peptide count & $p$-value & Subcellular localization & Protein level & $\begin{array}{l}\text { Phosphorylation } \\
\text { level }\end{array}$ \\
\hline \multicolumn{8}{|c|}{ Photosynthesis } \\
\hline L1 & $\begin{array}{l}\text { Ribulose-1,5-bisphosphate } \\
\text { carboxylase/oxygenase small } \\
\text { subunit }\end{array}$ & 300 & 18 & 0.021 & Chloroplast & Down & Down \\
\hline$\llcorner 4$ & $\begin{array}{l}\text { Ribulose-1,5-bisphosphate } \\
\text { carboxylase/oxygenase large } \\
\text { subunit }\end{array}$ & 1120 & 30 & 0.03 & Chloroplast & Down & Down \\
\hline L5 & $\begin{array}{l}\text { Ribulose-1,5-bisphosphate } \\
\text { carboxylase/oxygenase large } \\
\text { subunit }\end{array}$ & 695 & 29 & 0.024 & Chloroplast & Up & Up \\
\hline L8 & $\begin{array}{l}\text { Chlorophyll a-b binding protein } \\
\text { 8, chloroplastic }\end{array}$ & 111 & 5 & 0.041 & Chloroplast & Up & Up \\
\hline L9 & $\begin{array}{l}\text { Chlorophyll a-b binding protein, } \\
\text { chloroplastic }\end{array}$ & 399 & 10 & 0.028 & Chloroplast & Up & Up \\
\hline L10 & $\begin{array}{l}\text { Ribulose bisphosphate car- } \\
\text { boxylase/oxygenase activase } \\
\text { A, partial }\end{array}$ & 363 & 17 & 0.029 & Chloroplast & Down & Down- \\
\hline L11 & $\begin{array}{l}\text { Ribulose bisphosphate car- } \\
\text { boxylase/oxygenase activase } \\
\text { A, partial }\end{array}$ & 402 & 17 & 0.042 & Chloroplast & Down & Down- \\
\hline L14 & $\begin{array}{l}\text { RuBisCO large subunit-binding } \\
\text { protein subunit beta }\end{array}$ & 1030 & 20 & 0.013 & Chloroplast & Down & Down \\
\hline G1 & $\begin{array}{l}\text { Ribulose-1,5-bisphosphate } \\
\text { carboxylase/oxygenase large } \\
\text { subunit, partial }\end{array}$ & 166 & 10 & 0.038 & Chloroplast & Up & Down \\
\hline \multicolumn{8}{|c|}{ Energy metabolism } \\
\hline L13 & $\begin{array}{l}\text { Ribulose bisphosphate carboxy- } \\
\text { lase activase B }\end{array}$ & 539 & 18 & 0.031 & Chloroplast & Up & Up \\
\hline L16 & $\begin{array}{l}\text { Fructose-bisphosphate aldolase, } \\
\text { cytoplasmic isozyme } 1\end{array}$ & 606 & 24 & 0.019 & Cytoplasm & Up & Up \\
\hline L17 & $\begin{array}{l}\text { Chloroplast fructose-1,6-biphos- } \\
\text { phate aldolase }\end{array}$ & 490 & 17 & 0.035 & Chloroplast & Up & Up \\
\hline L19 & ATP synthase subunit & 255 & 20 & 0.043 & Chloroplast & Down & Down \\
\hline L21 & $\begin{array}{l}\text { Phosphoglycerate kinase, chlo- } \\
\text { roplastic }\end{array}$ & 916 & 17 & 0.028 & Chloroplast & Up & Up \\
\hline L25 & V-type proton ATPase subunit B 1 & 538 & 36 & 0.019 & Chloroplast & Up & Up \\
\hline L26 & $\begin{array}{l}\text { ATP-dependent Clp protease } \\
\text { ATP-binding subunit clpA-like } \\
\text { protein CD4B }\end{array}$ & 383 & 38 & 0.02 & Chloroplast & Down & Up \\
\hline G2 & $\begin{array}{l}\text { Fructose-bisphosphate aldolase } \\
\text { cytoplasmic isozyme }\end{array}$ & 118 & 12 & 0.019 & Cytoplasm & Up & Up \\
\hline G4 & Triosephosphate-isomerase & 619 & 3 & 0.018 & Cytoplasm & Up & Up \\
\hline G5 & $\begin{array}{l}\text { Glyceraldehyde-3-phosphate } \\
\text { dehydrogenase }\end{array}$ & 75 & 14 & 0.032 & Cytoplasm & Down & Up \\
\hline G6 & Enolase & 366 & 18 & 0.018 & Cytoplasm & Down & Down \\
\hline G7 & Pyruvate, phosphate dikinase 1 & 491 & 39 & 0.018 & Chloroplast & Up & Up \\
\hline G8 & Dihydrolipoyl dehydrogenase & 253 & 23 & 0.015 & Mitochondrion & Up & Up \\
\hline G9 & Aconitate hydratase & 163 & 25 & 0.043 & Cytoplasm & Up & Up \\
\hline \multicolumn{8}{|c|}{ Storage substance biosynthesis } \\
\hline G10 & Sucrose synthase type 2 & 809 & 31 & 0.002 & Cytoplasm & Up & Up \\
\hline G11 & Sucrose synthase 2 & 432 & 35 & 0.028 & Cytoplasm & Up & Up \\
\hline G12 & Phosphoglucomutase & 476 & 18 & 0.019 & Cytoplasm & Up & Up \\
\hline \multicolumn{8}{|c|}{ Stress defense } \\
\hline G13 & Heat shock protein 101 & 916 & 40 & 0.039 & Nucleus & Up & Up \\
\hline
\end{tabular}


Table 1 (continued)

\begin{tabular}{|c|c|c|c|c|c|c|c|}
\hline Spot no. & Protein name & Protein score & Peptide count & $p$-value & Subcellular localization & Protein level & $\begin{array}{l}\text { Phosphorylation } \\
\text { level }\end{array}$ \\
\hline G14 & $\begin{array}{l}17.9 \mathrm{kDa} \text { class I heat shock } \\
\text { protein-like }\end{array}$ & 224 & 21 & 0.017 & Cytoplasm & Up & Up \\
\hline G15 & Oxalate oxidase 2 & 97 & 5 & 0.021 & Cell-Membrane & Up & Up \\
\hline G16 & Dehydroascorbate reductase & 812 & 15 & 0.035 & Cytoplasm & Up & Down \\
\hline G17 & Disease resistance protein RPP8 & 48 & 14 & 0.022 & Cytoplasmic & Up & Up \\
\hline G18 & Peroxidase 1 & 340 & 13 & 0.032 & Vacuole & Down & Up \\
\hline G19 & $\begin{array}{l}\text { Translationally-controlled tumor } \\
\text { protein }\end{array}$ & 552 & 16 & 0.022 & Cytoplasm & Down & Up+ \\
\hline G31 & $\begin{array}{l}\text { Hypothetical protein } \\
\text { TRIUR3_21260 }\end{array}$ & 632 & 8 & 0.006 & Cytoplasm & Down & Down \\
\hline G35 & Cold regulated protein & 210 & 6 & 0.021 & Cytoplasm & Down & Down \\
\hline G39 & $\begin{array}{l}\text { Translationally controlled tumor } \\
\text { protein }\end{array}$ & 264 & 7 & 0.021 & Cytoplasm & Up & Up \\
\hline \multicolumn{8}{|c|}{ Carbon metabolism } \\
\hline L20 & $\begin{array}{l}\text { Arabinoxylan arabinofuranohy- } \\
\text { drolase isoenzyme AXAH-II }\end{array}$ & 251 & 12 & 0.029 & Cell-Membrane & Up & Up \\
\hline L24 & Predicted protein & 316 & 14 & 0.039 & Chloroplast & Down & Up \\
\hline G24 & Basic endochitinase $C$ & 130 & 3 & 0.029 & Extracellular & Up & Down \\
\hline $\mathrm{G} 28$ & Formate dehydrogenase & 196 & 3 & 0.026 & Mitochondrion & Up & Up \\
\hline G30 & $\begin{array}{l}\text { Glucose and ribitol Dehydroge- } \\
\text { nase-like protein }\end{array}$ & 264 & 11 & 0.032 & Cytoplasm & Up & Down \\
\hline \multicolumn{8}{|c|}{ Protein biosynthesis and degradation } \\
\hline L18 & $\begin{array}{l}\text { Peptidyl-prolylcis-trans isomerase } \\
\text { CYP38 }\end{array}$ & 371 & 21 & 0.015 & Chloroplast & Down & Down \\
\hline L22 & Methionine synthase 1 enzyme & 391 & 27 & 0.032 & Cytoplasm & Down & Up \\
\hline L23 & Methionine synthase 1 enzyme & 391 & 27 & 0.006 & Cytoplasm & Down & Up \\
\hline G20 & Globulin-1 S allele & 416 & 16 & 0.024 & Vacuole & Up & Up \\
\hline $\mathrm{G} 22$ & Serpin-Z2B & 712 & 18 & 0.034 & Chloroplast & Down & Down \\
\hline G23 & $\begin{array}{l}\text { ATP-dependent zinc metallopro- } \\
\text { tease FTSH } 2\end{array}$ & 53 & 12 & 0.027 & Chloroplast & Up & Up \\
\hline $\mathrm{G} 25$ & Alanine aminotransferase 2 & 304 & 22 & 0.017 & Cytoplasm & Down & Up \\
\hline G27 & Serpin 1 & 500 & 17 & 0.041 & Extracellular & Up & Down \\
\hline G32 & Putative methionine synthase & 157 & 1 & 0.014 & Cytoplasm & Up & Up \\
\hline G33 & Aspartate aminotransferase & 194 & 9 & 0.021 & Cytoplasm & Down & Up \\
\hline G34 & Globulin 3 & 489 & 20 & 0.017 & Vacuole & Down & Up \\
\hline G37 & Elongation factor 1-beta & 159 & 4 & 0.042 & Vacuole & Down & Down \\
\hline
\end{tabular}

Up: upregulated in phosphorylation level; Down: downregulated in phosphorylation level. Up+: the phosphoproteins were only identified in drought treatment. Down-: the phosphoproteins were only identified in CK

phosphorylated proteins were predicted by NetPhos 3.1 Server. High scores $(\geq 0.90)$ were set to increase the accuracy of prediction and the results are shown in Additional file 1: Table S4A, B. In total, 58 phosphorylated proteins contained 543 phosphorylated peptides, of which 191 were from flag leaves and 352 from developing grains (Additional file 2: Fig. S1a). Combined with functional categories, we found that phosphorylated proteins related to energy metabolism contained the most phosphorylated sites, including $73(38.22 \%)$ from flag leaves and $76(21.59 \%)$ from grains (Fig. 7a). The second largest category was those related to protein metabolism, which accounted for $26.70 \%$ (51) in flag leaves and $21.02 \%$ (74) in developing grains. Generally, both flag leaves and grains had similar percentages of serine $(74 \%)$, threonine (14\%) and tyrosine (12\%) phosphorylation (Additional file 2: Fig. S1b, d). Thus, consistent with the previous reports (Zhang et al. 2014a, b), serine phosphorylation had the highest percentage among three phosphorylated amino acid residues.

Western blotting was performed to further verify the identified phosphorylated proteins using an 


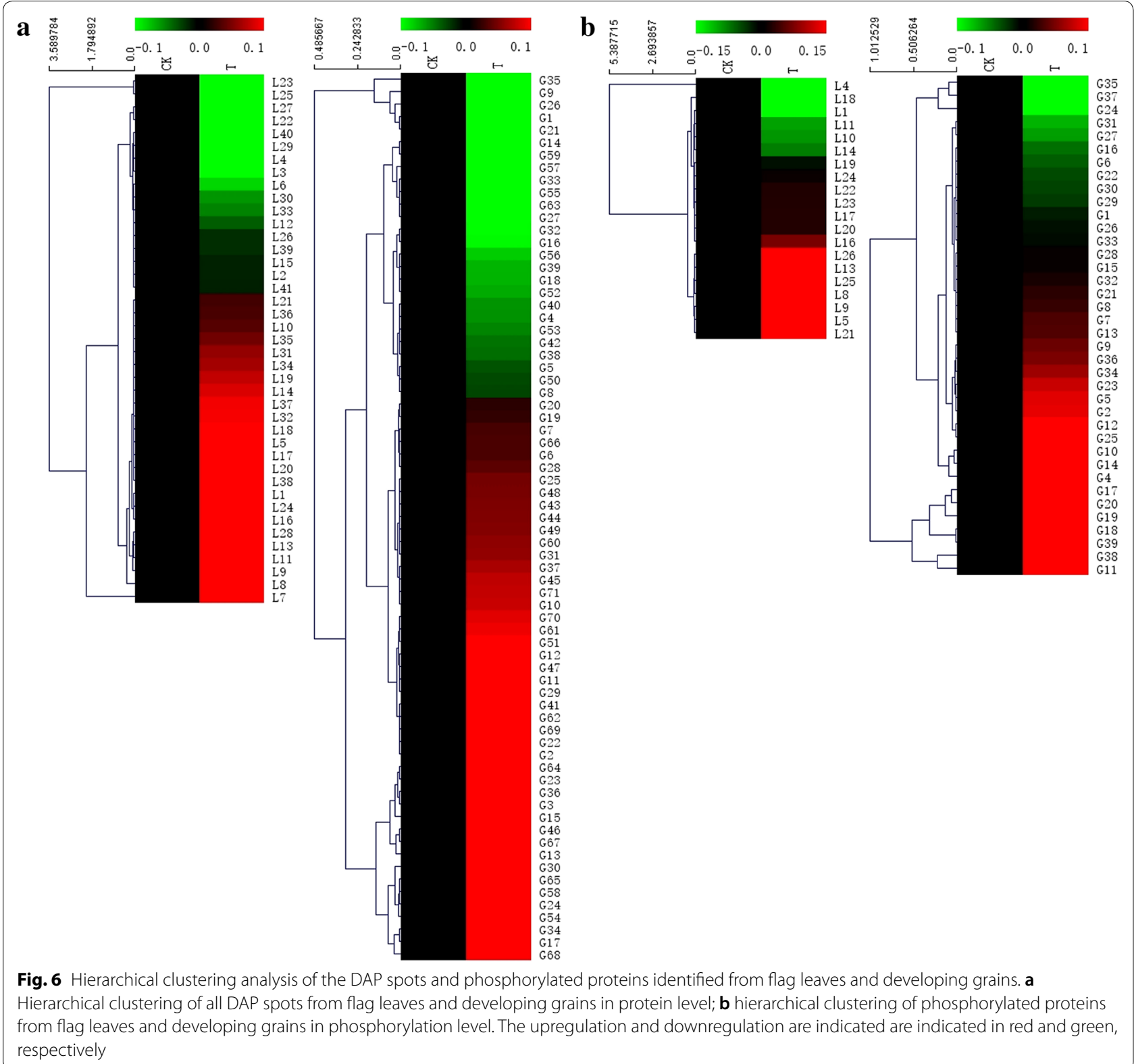

Anti-Phosphoserine/threonine/tyrosine monoclonal antibody (Fig. 7b, c). Through comparison of Western blotting results with 2-DE and Pro-Q Diamond gels, the results showed that 16 phosphorylated proteins, including 7 from flag leaves (Fig. 7b) and 9 from developing grains (Fig. 7c) were confirmed to be phosphorylated, such as ribulose-1,5-bisphosphate carboxylase/ oxygenase large subunit, phosphoglycerate kinase, chloroplastic and formate dehydrogenase etc. These phosphorylated proteins shown in Fig. 7b, c were well corresponding to Pro-Q Diamond staining results listed in Table 1.

\section{Discussion}

Phosphorylated proteins participating in photosynthesis regulation

Photosynthesis is an essential metabolic process that directly impacts carbohydrate synthesis, grain development and yield formation. Phosphorylation of chloroplast membrane proteins is ultimately responsible in plants, responding to changes in incident light and redox poise (Allen 1983, 1992a). Light-harvesting complex II (LHCII), the chloroplast light-harvesting chlorophyll a/b-binding complex, is a major substrate protein of phosphorylation, which binds perhaps half of the chlorophyll in nature. It is 

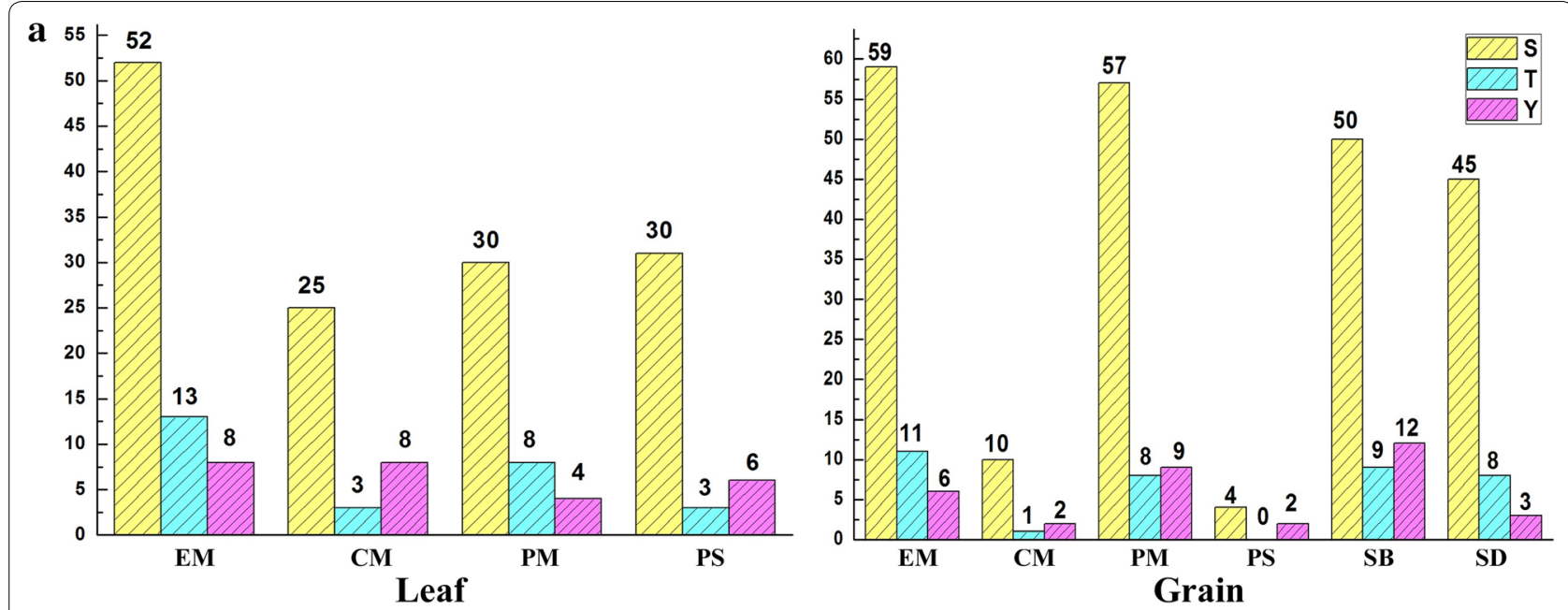

b
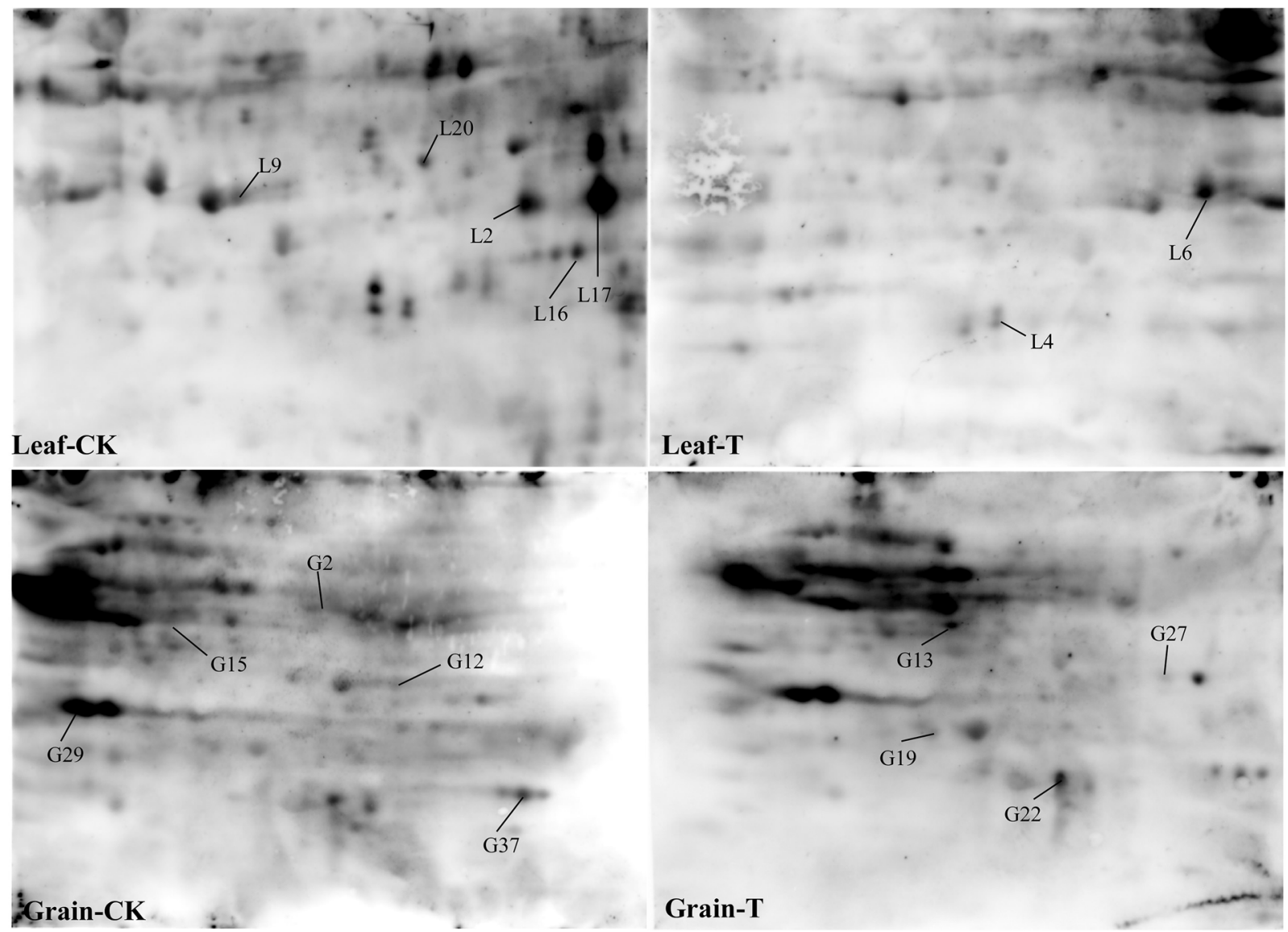

\section{Grain-CK}

\section{Grain-T}

Fig. 7 Prediction of phosphorylated site by phosphorylation site software and verification of phosphoproteins by Western-blotting. a The numbers of serine/threonine/tyrosine predictive phosphorylation sites in main functional groups in flag leaf and grain. S: phosphosites in serine residues, T: phosphosites threonine residues, Y: phosphosites tyrosine residues. EM: energy metabolism; CM: carbon metabolism; PM: protein metabolism; PS: photosynthesis; SB: Starch biosynthesis; SD: stress defense. b Western-blotting analysis in leaves of CK and drought treatment group, respectively. $\mathbf{c}$ Western-blotting analysis in the grains of CK and drought treatment group. All the gels used to perform Western blotting were chosen from red box in Fig. 5 
known that the light-harvesting complex changes its allegiance upon phosphorylation. Phosphorylated proteins have a great effect on enzyme structure, specificity or activities such as glycogen phosphorylase and isocitrate dehydrogenase and therefore play a key role in photosynthesis (Allen 1992b). In this study, we identified several phosphorylated proteins associated with photosynthesis in flag leaves, including a series of ribulose-1,5-bisphosphate carboxylase/oxygenase (Rubisco) proteins, chlorophyll $\mathrm{a}-\mathrm{b}$ binding proteins (CBPs, L8-L9) and ribulose bisphosphate carboxylase/oxygenase activase (L10-L13). One phosphorylated Rubisco protein in response to water deficit was also identified in the developing grains (G1) (Table 1). This indicates that photosynthesis also happened in grains when subjected to drought stress, which could be beneficial for grain development. Meanwhile, we found that most phosphoproteins involved in photosynthesis were downregulated in protein modification level as well as protein level, which could be responsible for the reduction of photosynthesis and grain yield.

Rubisco initiates both the photosynthetic carbon reduction and photorespiratory carbon oxidation cycles (Bowes 1991). Rubisco large subunit binding protein (RSBL) is involved in the assembly of Rubisco in higher plant chloroplasts, which can be dissociated to monomeric subunits with binding ATP, but re-attached by removal of ATP (Musgrove and Ellis 1986). We found that both the expression level and the phosphorylated level of this protein are downregulated under drought treatment (Table 1), suggesting that the assembly of Rubisco and photosynthesis were heavily restrained under drought stress. Rate of photosynthesis is heavily dependent on the activity of Rubisco proteins (Chaitanya et al. 2002). Drought normally diminishes the biochemical capacity for carbon assimilation and utilization (Reddy et al. 2004). We found that the phosphorylated level of Rubisco was downregulated in flag leaves, suggesting that drought inhibits photosynthesis mainly through reducing phosphorylation modification level of Rubisco. Rubisco activase has the function of activating Rubisco (Feller et al. 1998). It was only identified by Pro-Q diamond staining in well-watered flag leaves, suggesting that this protein was dephosphorylated duo to drought stress. Rubisco activase mediates Rubisco, which is ATP-dependent (Feller et al. 1998). We found that drought heavily inhibited phosphorylation of Rubisco activase and affected the activity of Rubisco activase. Thus, the function of photosynthesis was severely disturbed, ultimately leading to grain yield decrease.

CBP, a light-harvesting complex serves as a light receptor and has diverse functions (Bassi et al. 1992). It captures and delivers excitation energy to photosystems. In this study, both phosphorylation and protein levels of
CBP and CBP 8 were upregulated under drought stress in the leaf, consistent with the recent report (Bian et al. 2017). This suggests that a few phosphorylated proteins such as CBP were upregulated to alleviate the influences on photosynthesis when suffered from drought stress.

\section{Phosphorylated proteins involved in energy metabolism}

Energy metabolism is basic radical cellular activity to maintain normal growth and development, which involves in three respiratory pathways: glycolysis, themitochondrial electron transport chain, and TCA cycle. These pathways are essential for energy supply to numerous cellular functions and greatly depend on phosphorylation of proteins (Fernie et al. 2004). In this study, energy metabolism related phosphorylated proteins accounted for a great proportion in function categories in both flag leaves and grains. Among them, 5 DAPs involved in glycolysis with an upregulation at 20 DPA of grain development in both protein and phosphorylaed modification levels, including fructose-bisphosphate aldolase (FBA) cytoplasmic isozyme (G2-G3), triosephosphate isomerase (G4), glyceraldehyde-3-phosphate dehydrogenase (GAPDH, G5), enolase (G6) and pyruvate phosphate dikinase (G7) (Table 1). In the flag leaf, two FBAs (L16-L17) were upregulated, one of which located in cytoplasm and the other in chloroplast. This indicated that drought expedited energy metabolism in both flag leaf and grain development, consistent with the previous reports (Caruso et al. 2009; Budak et al. 2013).

Two enzymes (dihydrolipoyl dehydrogenase and aconitate hydratase, G8 and G9) involved in TCA cycle were identified in this study. Both of them were up-regulated at protein and phosphoprotein level at 20 DPA of developing grains. The pyruvate dehydrogenase complex (PDC), consisting of dihydrolipoyl dehydrogenase, catalyzes the irreversible conversion of pyruvate, coenzyme $\mathrm{A}$ and NAD+ into $\mathrm{CO}_{2}, \mathrm{NADH}$ and acetyl-CoA (Patel and Roche 1990). Obviously, TCA cycle has similar trend to glycolysis, and plants increased TCA cycle and glycolysis metabolism in the developing grains to provide sufficient energy for starch biosynthesis. Similar report also showed that the ATP/ADP ratio was significantly increased in spring wheat plants under drought stress (Chen et al. 2004).

Starch biosynthesis regulation via protein phosphorylation Starch biosynthesis needs abundant triosephosphates provided by photosynthesis in the early grain development stages (Tschiersch et al. 2011). A large number of phosphorylated enzymes related to starch biosynthesis were needed to transform intermediates of photosynthesis into starch (Tschiersch et al. 2011). In this study, we identified two key enzymes involved in starch 
biosynthesis: sucrose synthase (G10, G11) and phosphoglucomutase (PGM, G12). Phosphorylation of these proteins could be induced by drought stress (Zhang et al. 2014a) and high-nitrogen (Zhen et al. 2017). At the beginning of starch biosynthesis, ADP glucose pyrophosphorylase (ADPase) catalyzes the first committed step of the starch biosynthetic pathway, converting glucose 1-phosphate and ATP to glucosyl moiety of ADP (ADPG) and pyrophosphate (Tschiersch et al. 2011). Then, ADPG is metabolized by sucrose synthase (SS) as it arrives in the cytosol of endosperm cells (Tomlinson and Denyer 2003). SS catalyzes starch biosynthesis by transferring the ADPG glucose to the non-reducing end of an existing $\alpha$-1,4-glucan chain. It has reported that loss of SSII in $T$. aestivum and $H$. vulgare endosperms causes a drastic reduction in amylopectin synthesis and abolishes binding of SSI, SBEIIa, and SBEIIb to the starch granules (Yamamori et al. 2000). We found that the phosphorylation level as well as protein level of SS was upregulation under drought stress, which could enhance enzyme activity and protein-protein interactions (Tetlow et al. 2004), and expedite starch biosynthesis and grain development under water deficit environment.

PGM has function of interconverting glucose-1-phosphate and glucose-6-phosphate, with glucose 1,6-bisphosphate as a cofactor (Ray et al. 1983). It has function that the transfer of a phosphoryl group from the itself to glucose 1-phosphate, forming glucose 1,6-bisphosphate (Najjar and Pullman 1954). The glucose-1-phosphate can be supplied in chloroplast phosphoglucomutase through the reductive pentose phosphate pathway (Smith and Martin 1993). However, it could be directly supplied by cytosol (Tyson and Rees 1988) or synthesized with the catalysis of a plastidial phosphoglucomutase in nonphotosynthetic tissues (Hill and Smith 1991). The biochemistry reaction catalyzed by PGM is a principal distinction in carbon and starch synthesis pathways. According to our results, PGM was unregulated in both phosphorylation and protein levels at 20 DPA of developing grains under drought stress conditions, which might boost to transform glucose-6-phosphate to glucose-1-phosphate. Thus, grain filling was advanced by drought stress due to acceleration of starch biosynthesis, consistent with energy metabolism in the developing grains.

\section{Protein phosphorylation regulating plant drought stress response}

During grain development, many hydrophobic proteins were gradually synthesized and accumulated to protect cells from various adverse environments (Zhang et al. 2014a). Drought has a severe limitation on wheat growth and yield formation. In this study, several proteins under drought conditions were found to be phosphorylated and up-regulated as well as in protein level, including 2 heat shock proteins (G13 and G14), one manganese ion binding protein (oxalate oxidase 2, G15), dehydroascorbate reductase (DHAR, G16), disease resistance protein RPP8 (G17), peroxidase 1 (G18) and translationally-controlled tumor protein (TCTP, G19). Particularly, the phosphorylation of TCTP was specifically induced by drought stress, suggesting its important roles in resistance to drought stress. TCTP is a calcium-binding protein (Sanchez et al. 1997) as well as tubulin-binding protein that associates with microtubules (Vandre et al. 1991). The expression level of plant TCTP could increase in response to abiotic stresses such as salt (Santa Brígida et al. 2014) and drought (Kim et al. 2012). TCTP could be phosphorylated at serine residues 46 and 64 by a polo-like protein kinase that regulates spindle function (Jung et al. 2004).

Plants are easily damaged by accumulated ROS under drought stress, including singlet oxygen, superoxide radical $\left(\mathrm{O}^{2-}\right)$, hydrogen peroxide $\left(\mathrm{H}_{2} \mathrm{O}_{2}\right)$, and hydroxyl radical $(\mathrm{OH})$ (Smith and Martin 1993). Many biological processes such as stress responses, hormone signaling, cell growth, and development, are related to ROS (Pei et al. 2000). Therefore, it is highly important for plants to scavenge high levels of ROS when suffered from drought. It is known that the ascorbate-glutathione (AsA-GSH) cycle is particularly important in plant antioxidant defense mechanism. Four anti-oxidative enzymes participate in ascorbate-glutathione cycle, including ascorbate peroxidase (APX), monodehydroascorbate reductase, dehydroascorbate reductase (DHAR), and glutathione reductase. In this study, a DHAR was identified in the drought treatment group at 20 DPA of developing grains, which is an indispensable enzyme functioning in the regeneration of ascorbate and glutathione that scavenges hydrogen peroxide and reduces it to water, with concomitant oxidation of NADPH (Eltayeb et al. 2006). Meanwhile, its phosphorylation and protein levels were up-regulated under drought stress, in accordance with our conjecture that drought stress may transform into oxidative stress, and proteins phosphorylated modification plays a key role to respond drought stress. The other anti-oxidative enzymes peroxidase 1 was also upregulated in grains, which is a key capable enzyme of removing ROS (De Pinto et al. 2006). Their phosphorylation could enhance ROS scavenging and drought tolerance.

Under abiotic stresses, maintaining proteins in their functional conformations and preventing protein misfolding are highly important for cell survival (Kim et al. 2013). Heat-shock proteins (Hsps) function in protein folding, assembly, translocation and degradation as well as assistance in protein refolding under stress conditions (Boston et al. 1996). Thus, Hsp family plays an imperative role in protecting plants against stress by 
re-establishing normal protein structure and cellular homeostasis (Bukau and Horwich 1998). Up-regulation of two Hsps was identified with enhancement in modification and expression level in this study. Hsp 101 can augment Arabidopsis resistance to thermo stress (Queitsch 2000). To our knowledge, the mechanism of HSP 101 functioned in adverse response is still not clear. Its phosphorylation was also found in wheat developing grains (Guo et al. 2012). The $17.9 \mathrm{kDa}$ class I heat shock protein-like was found to be upregulated under drought stress in both phosphorylation and protein accumulation levels. We speculate that the phosphorylation of Hsp family may be an important mechanism in response to drought stress.

\section{Conclusion}

This study identified 58 phosphorylated proteins among 112 differentially accumulated proteins in response to water deficit at 20 days of postanthesis, including 20 in the flag leaves and 38 in the developing grains. The phosphorylated proteins from flag leaves mainly involved in photosynthesis, carbohydrate metabolism and energy metabolism while those from developing grains mainly participated in detoxification and defense, protein metabolism, carbohydrate metabolism and energy metabolism. Most phosphoproteins related to photosynthesis in flag leaves were significantly downregulated such as ribulose1,5-bisphosphate carboxylase/oxygenase large subunit, ribulose bisphosphate carboxylase/oxygenase activase, leading to significant decrease in starch biosynthesis and grain yield. On the contrary, most phosphoproteins associated with drought stress response as well as energy metabolism were upregulated in the developing grains, demonstrating the important roles of protein phosphorylation in resisting to drought, and expediting starch biosynthesis and grain filling. Our results provide new evidence for protein phosphorylated modification how to regulate plant drought tolerance and grain development.

\section{Additional files}

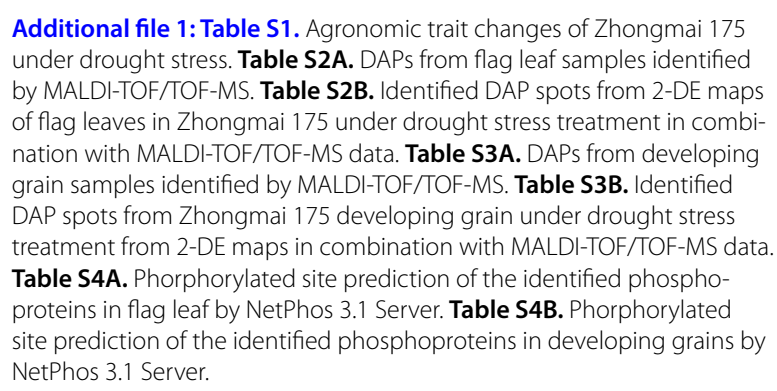

Additional file 2: Fig. S1. Statistics of predicted phosphorylation sites. (a) The numbers of serine/threonine/tyrosine phosphorylated sites in flag leaves and developing grains, respectively. (b), (c) and (d) represented the percentage of serine residues/threonine residues/tyrosine residues phosphorylation in flag leaves, developing grains and all phosphorylated sites, respectively.

\section{Abbreviations}

2-DE: two-dimensional electrophoresis; AGPase: ADP glucose pyrophosphorylase; APX: ascorbate peroxidase; CBPs: chlorophyll a-b binding proteins; DAPs: differentially accumulated proteins; DHAR: dehydroascorbate reductase; DHAR: dehydroascorbate reductase; DPA: days postanthesis; FBA: fructosebisphosphate aldolase; GAPDH: glyceraldehyde-3-phosphate dehydrogenase; Hsps: heat-shock proteins; MALDI-TOF/TOF-MS: matrix-assisted laser desorption/ionisation time-of-flight/time-of-flight mass spectrometry; NCBI: National Center for Biotechnology Information; PDC: pyruvate dehydrogenase complex; PGM: phosphoglucomutase; PTMs: protein posttranslational modifications; ROS: reactive oxygen species; Rubisco: ribulose-1,5-bisphosphate carboxylase/oxygenase; SDS-PAGE: sodium dodecyl sulfate-polyacrylamide gel electrophoresis; SS: starch synthases; TCTP: translationally-controlled tumor protein.

\section{Authors' contributions}

YY designed the experiments. FL witted this paper, conducted the experiment and analyzed experimental data. XD collected materials and measured agronomic trait. YL reviewed the manuscript. All authors read and approved the final manuscript.

\section{Author details}

${ }^{1}$ College of Life Science, Capital Normal University, Beijing 100048, China. ${ }^{2}$ Hubei Collaborative Innovation Center for Grain Industry (HCICGI), Yangtze University, Jingzhou 434025, China.

\section{Competing interests}

The authors declare that they have no competing interests.

\section{Availability of data and materials}

All data generated or analysed during this study are included in this published article [and its additional files].

\section{Consent for publication}

Authors agree to the terms of the Springer Open Copyright and License Agreement.

\section{Ethics approval and consent to participate}

Not applicable, the study involves no human participants.

Funding

This research was financially supported by the Grant from the National Natural Science Foundation of China (31771773).

\section{Publisher's Note}

Springer Nature remains neutral with regard to jurisdictional claims in published maps and institutional affiliations.

Received: 28 August 2018 Accepted: 3 December 2018

Published online: 08 December 2018

\section{References}

Aivaliotis M, Macek B, Gnad F, Reichelt P, Mann M, Oesterhelt D (2009) Ser/Thr/Tyr protein phosphorylation in the archaeon Halobacterium salinarum - a representative of the third domain of life. PLoS ONE 4:e4777. https://doi.org/10.1371/journal.pone.0004777

Allen JF (1983) Protein phosphorylation-carburettor of photosynthesis? Trends Biochem Sci 8:369-373. https://doi.org/10.1016/09680004(83)90364-X 
Allen JF (1992a) Protein phosphorylation in regulation of photosynthesis. Biochim Biophys Acta Bioenerg 1098:275-335. https://doi.org/10.1016/ S0005-2728(09)91014-3

Allen JF (1992b) How does protein phosphorylation regulate photosynthesis? Trends Biochem Sci 17:12-17. https://doi.org/10.1016/09680004(92)90418-9

Araus JL, Tapia L (1987) Photosynthetic gas exchange characteristics of wheat flag leaf blades and sheaths during grain filling: the case of a spring crop grown under mediterranean climate conditions. Plant Physiol 85:667673. https://doi.org/10.1104/pp.85.3.667

Bassi R, Soen Su Yin, Frank G, Zuber H, Rochaix JD (1992) Characterization of chlorophyll a/b proteins of photosystem I from Chlamydomonas reinhardtii. J Biol Chem 267:25714-25721

Bian Y, Deng X, Yan X, Zhou J, Yuan L, Yan Y (2017) Integrated proteomic analysis of Brachypodium distachyon roots and leaves reveals a synergistic network in the response to drought stress and recovery. Sci Rep 7:46183. https://doi.org/10.1038/srep46183

Blom N, Gammeltoft S, Brunak S (1999) Sequence and structure-based prediction of eukaryotic protein phosphorylation sites. J Mol Biol 294:13511362. https://doi.org/10.1006/jmbi.1999.3310

Boston RS, Viitanen PV, Vierling E (1996) Molecular chaperones and protein folding in plants. Plant Mol Biol 32:191-222. https://doi.org/10.1007/ BF00039383

Bowes $\mathrm{G}$ (1991) Growth at elevated $\mathrm{CO}_{2}$ : photosynthetic responses mediated through Rubisco. Plant Cell Environ 14:795-806. https://doi. org/10.1111/j.1365-3040.1991.tb01443.x

Budak H, Akpinar BA, Unver T, Turktas M (2013) Proteome changes in wild and modern wheat leaves upon drought stress by two-dimensional electrophoresis and nanoLC-ESI-MS/MS. Plant Mol Biol 83:89-103. https://doi. org/10.1007/s11103-013-0024-5

Bukau B, Horwich AL (1998) The Hsp70 and Hsp60 chaperone machines. Cell 92:351-366. https://doi.org/10.1016/S0092-8674(00)80928-9

Cai W, Cowan T, Thatcher M (2012) Rainfall reductions over Southern Hemisphere semi-arid regions: the role of subtropical dry zone expansion. Sci Rep 2:702. https://doi.org/10.1038/srep00702

Cao H, Yan X, Chen G, Zhou J, Li X, Ma W, Yan Y (2015) Comparative proteome analysis of A- and B-type starch granule-associated proteins in bread wheat (Triticum aestivum L.) and Aegilops crassa. J. Proteomics 112:95-112. https://doi.org/10.1016/j.jprot.2014.08.002

Caruso G, Cavaliere C, Foglia P, Gubbiotti R, Samperi R, Laganà A (2009) Analysis of drought responsive proteins in wheat (Triticum durum) by 2D-PAGE and MALDI-TOF mass spectrometry. Plant Sci 177:570-576. https://doi. org/10.1016/J.PLANTSCI.2009.08.007

Chaitanya KV, Masilamani S, Jutur PP, Reddy AR (2002) Variation in photosynthetic rates and biomass productivity among four mulberry cultivars. Photosynthetica 40:305-308. https://doi.org/10.1023/A:1021318412861

Chang I-F, Hsu J-L, Hsu P-H, Sheng W-A, Lai S-J, Lee C, Chen C-W, Hsu J-C, Wang S-Y, Wang L-Y, Chen C-C (2012) Comparative phosphoproteomic analysis of microsomal fractions of Arabidopsis thaliana and Oryza sativa subjected to high salinity. Plant Sci 185-186:131-142. https://doi. org/10.1016/j.plantsci.2011.09.009

Chen K-M, Gong H-J, Chen G-C, Wang S-M, Zhang C-L (2004) Gradual drought under field conditions influences the glutathione metabolism, redox balance and energy supply in spring wheat. J Plant Growth Regul 23:20-28. https://doi.org/10.1007/s00344-003-0053-4

Chen G, Zhu J, Zhou J, Subburaj S, Zhang M, Han C, Hao P, Li X, Yan Y (2014) Dynamic development of starch granules and the regulation of starch biosynthesis in Brachypodium distachyon: comparison with common wheat and Aegilops peregrina. BMC Plant Biol 14:198. https://doi. org/10.1186/s12870-014-0198-2

Chen G-X, Zhen S-M, Liu Y-L, Yan X, Zhang M, Yan Y-M (2017) In vivo phosphoproteome characterization reveals key starch granule-binding phosphoproteins involved in wheat water-deficit response. BMC Plant Biol 17:168. https://doi.org/10.1186/s12870-017-1118-Z

Chu P, Zhang Y, Yu Z, Guo Z, Shi Y (2016) Winter wheat grain yield, water use, biomass accumulation and remobilisation under tillage in the North China Plain. F Crop Res 193:43-53. https://doi.org/10.1016/J. FCR.2016.03.005

Cohen P (2002) The origins of protein phosphorylation. Nat Cell Biol 4:E127E130. https://doi.org/10.1038/ncb0502-e127
Cornic G (2000) Drought stress inhibits photosynthesis by decreasing stomatal aperture - not by affecting ATP synthesis. Trends Plant Sci 5:187-188. https://doi.org/10.1016/S1360-1385(00)01625-3

De Pinto MC, Paradiso A, Leonetti P, De Gara L (2006) Hydrogen peroxide, nitric oxide and cytosolic ascorbate peroxidase at the crossroad between defence and cell death. Plant J 48:784-795. https://doi. org/10.1111/j.1365-313X.2006.02919.x

Dong K, Zhen S, Cheng Z, Cao H, Ge P, Yan Y (2015) Proteomic analysis reveals key proteins and phosphoproteins upon seed germination of wheat (Triticum aestivum L.). Front Plant Sci 6:1-14. https://doi. org/10.3389/fpls.2015.01017

Donner DA, Mesdag J (2000) Bread-making quality of wheat: a century of breeding in Europe. Kluwer Academic Publishers, Wageningen

Eltayeb AE, Kawano N, Badawi GH, Kaminaka H, Sanekata T, Morishima I, Shibahara T, Inanaga S, Tanaka K (2006) Enhanced tolerance to ozone and drought stresses in transgenic tobacco overexpressing dehydroascorbate reductase in cytosol. Physiol Plant 127:57-65. https://doi. org/10.1111/j.1399-3054.2006.00624.x

Engelsberger WR, Schulze WX (2012) Nitrate and ammonium lead to distinct global dynamic phosphorylation patterns when resupplied to nitrogen-starved Arabidopsis seedlings. Plant J 69:978-995. https://doi. org/10.1111/j.1365-313X.2011.04848.x

Fedoroff NV, Battisti DS, Beachy RN, Cooper PJM, Fischhoff DA, Hodges CN, Knauf VC, Lobell D, Mazur BJ, Molden D, Reynolds MP, Ronald PC, Rosegrant MW, Sanchez PA, Vonshak A, Zhu J-K (2010) Radically rethinking agriculture for the 21 st century. Science 327:833-834. https ://doi.org/10.1126/science.1186834

Feller U, Crafts-Brandner SJ, Salvucci ME (1998) Moderately high temperatures inhibit ribulose-1,5-bisphosphate carboxylase/oxygenase (Rubisco) activase-mediated activation of Rubisco. Plant Physiol 116:539-546. https://doi.org/10.1104/pp.116.2.539

Fernie AR, Carrari F, Sweetlove LJ (2004) Respiratory metabolism: glycolysis, the TCA cycle and mitochondrial electron transport. Curr Opin Plant Biol 7:254-261. https://doi.org/10.1016/j.pbi.2004.03.007

Gardner WH (1986) Water content. Methods of soil analysis. In: Klute A (ed) Part 1. Agronomy monographs 9, 2nd edn. Verlag, American Society of Agronomy and Soil Science Society of America Madison, pp 493-544

Guo G, Lv D, Yan X, Subburaj S, Ge P, Li X, Hu Y, Yan Y (2012) Proteome characterization of developing grains in bread wheat cultivars (Triticum aestivum L.). BMC Plant Biol 12:147. https://doi. org/10.1186/1471-2229-12-147

Harb A, Krishnan A, Ambavaram MMR, Pereira A (2010) Molecular and physiological analysis of drought stress in Arabidopsis reveals early responses leading to acclimation in plant growth. Plant Physiol 154:1254-1271. https://doi.org/10.1104/pp.110.161752

Hill L, Smith A (1991) Evidence that glucose 6-phosphate is imported as the substrate for starch synthesis by the plastids of developing pea embryos. Planta 185:91-96. https://doi.org/10.1007/BF00194519

Horie T, Kaneko T, Sugimoto G, Sasano S, Panda SK, Shibasaka M, Katsuhara M (2011) Mechanisms of water transport mediated by PIP aquaporins and their regulation via phosphorylation events under salinity stress in barley roots. Plant Cell Physiol 52:663-675. https://doi.org/10.1093/ $\mathrm{pcp} / \mathrm{pcr027}$

Hu X, Li N, Wu L, Li C, Li C, Zhang L, Liu T, Wang W (2015a) Quantitative iTRAQ-based proteomic analysis of phosphoproteins and ABA-regulated phosphoproteins in maize leaves under osmotic stress. Sci. Rep 5:15626. https://doi.org/10.1038/srep15626

Hu X, Wu L, Zhao F, Zhang D, Li N, Zhu G, Li C, Wang W (2015b) Phosphoproteomic analysis of the response of maize leaves to drought, heat and their combination stress. Front Plant Sci 6:298. https://doi.org/10.3389/ fpls.2015.00298

Hunter T, Karin M (1992) The regulation of transcription by phosphorylation. Cell 70:375-387. https://doi.org/10.1016/0092-8674(92)90162-6

Johansson E, Prieto-Linde ML, Jönsson JÖ (2001) Effects of wheat cultivar and nitrogen application on storage protein composition and breadmaking quality. Cereal Chem 78:19-25. https://doi.org/10.1094/CCHEM 2001.78.1.19

Jung J, Kim M, Kim MJ, Kim J, Moon J, Lim JS, Kim M, Lee K (2004) Translationally controlled tumor protein interacts with the third cytoplasmic domain of $\mathrm{Na}$, K-ATPase a subunit and inhibits the pump activity in HeLa cells. J Biol Chem 279:49868-49875. https://doi.org/10.1074/jbc.M400895200 
Kersten B, Agrawal GK, Durek P, Neigenfind J, Schulze W, Walther D, Rakwal R (2009) Plant phosphoproteomics: an update. Proteomics 9:964-988. https:// doi.org/10.1002/pmic.200800548

Kim YM, Han YJ, Hwang OJ, Lee SS, Shin AY, Kim SY, II Kim J (2012) Overexpression of arabidopsis translationally controlled tumor protein gene AtTCTP enhances drought tolerance with rapid ABA-induced stomatal closure. Mol Cells 33:617-626. https://doi.org/10.1007/s10059-012-0080-8

Kim YE, Hipp MS, Bracher A, Hayer-Hartl M, Ulrich Hartl F (2013) Molecular chaperone functions in protein folding and proteostasis. Annu Rev Biochem 82:323-355. https://doi.org/10.1146/annurev-biochem-060208-092442

Lawlor DW, Cornic G (2002) Photosynthetic carbon assimilation and associated metabolism in relation to water deficits in higher plants. Plant Cell Environ 25:275-294. https://doi.org/10.1046/.0016-8025.2001.00814.x

Lobell DB, Schlenker W, Costa-Roberts J (2011) Climate trends and global crop production since 1980. Science 333:616-620. https://doi.org/10.1126/scien ce.1204531

Lv DW, Li X, Zhang M, Gu AQ, Zhen SM, Wang C, Li XH, Yan YM (2014a) Large-scale phosphoproteome analysis in seedling leaves of Brachypodium distachyon L. BMC Genomics 15:1-18. https://doi.org/10.1186/1471-2164-15-375

Lv D-W, Subburaj S, Cao M, Yan X, Li X, Appels R, Sun D-F, Ma W, Yan Y-M (2014b) Proteome and phosphoproteome characterization reveals new response and defense mechanisms of Brachypodium distachyon leaves under salt stress. Mol Cell Proteomics 13:632-652. https://doi.org/10.1074/mcp. M113.030171

Lv HQ, Zhang YS, Li MS et al (2015) [GB/T 32136-2015] Grade of agricultural drought. China Standards Press, Beijing

Lv D-W, Zhu G-R, Zhu D, Bian Y-W, Liang X-N, Cheng Z-W, Deng X, Yan Y-M (2016) Proteomic and phosphoproteomic analysis reveals the response and defense mechanism in leaves of diploid wheat T. monococcum under salt stress and recovery. J Proteomics 143:93-105. https://doi.org/10.1016/j.jprot 2016.04.013

MacRobbie EA (1998) Signal transduction and ion channels in guard cells. Philos Trans R Soc B 353:1475-1488. https://doi.org/10.1098/rstb.1998.0303

Musgrove J, Ellis R (1986) The rubisco large subunit binding protein. Philos Trans R Soc 313:419-428. https://doi.org/10.1007/BF00039488

Najjar VA, Pullman ME (1954) The occurrence of a group transfer involving enzyme (phosphoglucomutase) and substrate. Science 119(3097):631-634. https://doi.org/10.1126/science.119.3097.631

Patel MS, Roche TE (1990) Molecular biology and biochemistry of pyruvate dehydrogenase complexes. FASEB J 4:3224-3233. https://doi.org/10.1096/ FASEBJ.4.14.2227213

Pei Z-M, Murata Y, Benning G, Thomine S, Klüsener B, Allen GJ, Grill E, Schroeder II (2000) Calcium channels activated by hydrogen peroxide mediate abscisic acidsignalling in guard cells. Nature 406:731-734. https://doi. org/10.1038/35021067

Queitsch C (2000) Heat shock protein 101 plays a crucial role in thermotolerance in Arabidopsis. Plant Cell 12:479-492. https://doi.org/10.1105/tpc.12.4.479

Ray WJ, Hermodson MA, Puvathingal JM, Puvathingal JM (1983) The complete amino acid sequence of rabbit muscle phosphoglucomutase. J Biol Chem 258:9166-9174

Reddy AR, Chaitanya KV, Vivekanandan M (2004) Drought-induced responses of photosynthesis and antioxidant metabolism in higher plants. J Plant Physiol 161:1189-1202. https://doi.org/10.1016/j.jplph.2004.01.013

Sanchez J-C, Schaller D, Ravier F, Golaz O, Jaccoud S, Belet M, Wilkins MR, James R, Deshusses J, Hochstrasser D (1997) Translationally controlled tumor protein: a protein identified in several nontumoral cells including erythrocytes. Electrophoresis 18:150-155. https://doi.org/10.1002/elps.1150180127

Santa Brígida AB, dos Reis SP, de Nazaré Monteiro Costa C, Cardoso CMY, Lima AM, de Souza CRB (2014) Molecular cloning and characterization of a cassava translationally controlled tumor protein gene potentially related to salt stress response. Mol Biol Rep 41:1787-1797. https://doi.org/10.1007/s1103 3-014-3028-6

Silva-Sanchez C, Li H, Chen S (2015) Recent advances and challenges in plant phosphoproteomics. Proteomics 15:1127-1141. https://doi.org/10.1002/ pmic.201400410

Slafer GA, Andrade FH, Satorre EH (1990) Genetic-improvement effects on preanthesis physiological attributes related to wheat grain-yield. Field Crop Res 23:255-263. https://doi.org/10.1016/0378-4290(90)90058-J
Smith AM, Martin C (1993) Starch biosynthesis and the potential for its manipulation. Topics Biosynth Manip Plant Prod. https://doi. org/10.1007/978-94-011-2142-2_1

Stock JB, Ninfa AJ, Stock AM (1989) Protein phosphorylation and regulation of adaptive responses in bacteria. Microbiol Rev 53:450-490

Tetlow IJ, Wait R, Lu ZX, Akkasaeng R, Bowsher CG, Esposito S, Kosar-Hashemi B, Morell MK, Emes MJ (2004) Protein phosphorylation in amyloplasts regulates starch branching enzyme activity and protein-protein interactions. Plant Cell 16:694-708. https://doi.org/10.1105/tpc.017400

Thingholm TE, Jensen ON, Larsen MR (2009) Analytical strategies for phosphoproteomics. Proteomics 9:1451-1468. https://doi.org/10.1002/pmic.200800454

Tomlinson K, Denyer K (2003) Starch synthesis in cereal grains. Adv Bot Res 40:1-61. https://doi.org/10.1016/S0065-2296(05)40001-4

Tschiersch H, Borisjuk L, Rutten T, Rolletschek H (2011) Gradients of seed photosynthesis and its role for oxygen balancing. Biosystems 103:302-308. https ://doi.org/10.1016/J.BIOSYSTEMS.2010.08.007

Tyson RH, Rees T (1988) Starch synthesis by isolated amyloplasts from wheat endosperm. Planta 175:33-38. https://doi.org/10.1007/BF00402879

Umezawa T, Sugiyama N, Takahashi F, Anderson JC, Ishihama Y, Peck SC, Shinozaki K (2013) Genetics and phosphoproteomics reveal a protein phosphorylation network in the abscisic acid signaling pathway in Arabidopsis thaliana. Sci Signal 6:8. https://doi.org/10.1126/scisignal.2003509

Vandre DD, Centonze VE, Peloquin J, Tombes RM, Borisy GG (1991) Proteins of the mammalian mitotic spindle: phosphorylation/dephosphorylation of MAP-4 during mitosis. J Cell Sci 98:577-588

Wang H, Wu K, Liu Y, Wu Y, Wang X (2015) Integrative proteomics to understand the transmission mechanism of Barley yellow dwarf virus-GPV by its insect vector Rhopalosiphum padi. Sci Rep 5:10971. https://doi.org/10.1038/srep1 0971

Wang Y, Xu C, Zhang B, Wu M, Chen G (2017) Physiological and proteomic analysis of rice (Oryza sativa L.) in flag leaf during flowering stage and milk stage under drought stress. Plant Growth Regul 82:201-218. https://doi. org/10.1007/s10725-017-0252-9

Yamamori M, Fujita S, Hayakawa K, Matsuki J, Yasui T (2000) Genetic elimination of a starch granule protein, SGP-1, of wheat generates an altered starch with apparent high amylose. Theor Appl Genet 101:21-29. https://doi. org/10.3389/fpls.2017.00067

Yang J, Zhang J, Huang Z, Zhu Q, Wang L (2000) Remobilization of carbon reserves is improved by controlled soil-drying during grain filling of wheat. Crop Sci 40:1645. https://doi.org/10.2135/cropsci2000.4061645x

Yang J, Zhang J, Wang Z, Zhu Q, Liu L (2001) Water deficit-induced senescence and its relationship to the remobilization of pre-stored carbon in wheat during grain filling. Agron J 93:196. https://doi.org/10.2134/agronj2001.931196x

Yu Y, Zhu D, Ma C, Cao H, Wang Y, Xu Y, Zhang W, Yan Y (2016) Transcriptome analysis reveals key differentially expressed genes involved in wheat grain development. Crop J 4:92-106. https://doi.org/10.1016/..cj.2016.01.006

Yuan LL, Zhang M, Yan X, Bian YW, Zhen SM, Yan YM (2016) Dynamic phosphoproteome analysis of seedling leaves in Brachypodium distachyon $\mathrm{L}$. reveals central phosphorylated proteins involved in the drought stress response. Sci Rep 6:1-14. https://doi.org/10.1038/srep35280

Zadoks JC, Chang TT, Konzak CF (1974) A decimal code for the growth stages of cereals. Weed Res 14:415-421. https://doi.org/10.1111/j.1365-3180.1974. tb01084.x

Zhang M, Lv D, Ge P, Bian Y, Chen G, Zhu G, Li X, Yan Y (2014a) Phosphoproteome analysis reveals new drought response and defense mechanisms of seedling leaves in bread wheat (Triticum aestivum L.). J Proteomics 109:290-308. https://doi.org/10.1016/.jprot.2014.07.010

Zhang M, Ma CY, Lv DW, Zhen SM, Li XH, Yan YM (2014b) Comparative phosphoproteome analysis of the developing grains in bread wheat (Triticum aestivum L.) under well-watered and water-deficit conditions. J Proteome Res 13:4281-4297. https://doi.org/10.1021/pr500400t

Zhen S, Deng X, Zhang M, Zhu G, Lv D, Wang Y, Zhu D, Yan Y (2017) Comparative phosphoproteomic analysis under high-nitrogen fertilizer reveals central phosphoproteins promoting wheat grain starch and protein synthesis. Front Plant Sci 8:67. https://doi.org/10.3389/fpls.2017.00067

Zhu J-K (2002) Salt and drought stress signal transduction in plants. Annu Rev Plant Biol 53:247-273. https://doi.org/10.1146/annurev.arplant.53.09140 1.143329 